\title{
ECOTOURISM IN THE STATE FOREST KARST OF PUERTO RICO
}

\author{
Andrea Hall and Mick Day \\ Department of Geography, University of Wisconsin-Milwaukee, PO Box 413, Milwaukee,WI 53201, andrea.brooke.hall@gmail.com,mickday@uwm.edu
}

\begin{abstract}
Ecotourism and nature-based tourism in karst landscapes are often focused on protected areas and are significant both economically and because of potential impacts. Karst covers nearly a third of the highly urbanized island of Puerto Rico, especially adjacent to the north coast and in the southwest. Much of the island's natureoriented tourism is focused on the karst, because it is the least-fragmented remaining habitat. The authors conducted a literature review and collected data during field research in 2009. The results indicate that the five state (or commonwealth) forests located within the karst of Puerto Rico are a primary focus of ecotourism because they are readily accessible and represent an important resource for low-impact recreation and education. The forests are used by residents and visitors, and they provide opportunities for appreciation and enjoyment of the karst landscape. Ecotourism activities focused on the state forests include hiking, bird-watching, and learning about nature. Without the state forests, levels of ecotourism within the karst would be considerably constrained. So, although they are limited in numbers and extent, they provide a critical recreational and economic resource in the karst landscape.
\end{abstract}

\section{INTRODUCTION}

Protected areas play a critical role in human use of karst areas, particularly in providing a buffer against exploitation of the natural landscape and in the burgeoning realms of recreation and tourism. Karst landscapes provide significant venues for ecotourism (e.g., Bundschuh et al., 2007), and the protected areas within karst can be important for promoting recreational and tourism opportunities (Scott et al., 2004). Few studies have examined this topic in detail, with most past studies specifically related to tourist-cave development and conservation (Lobo and Moretti, 2009; Cigna and Burri, 2000) and not ecotourism within the karst environment as a whole; a particularly striking example of the latter case is presented here.

Caribbean karst landscapes have been subject to longterm and intense human pressure, and tourism is a human activity that is of increasing significance (Day, 1993). Tourism impacts karst, particularly because of the relative fragility of the landscape (Day, 2010a,b, 2011), and even eco-related activities can damage the environment, particularly in karst landscapes (Coghlan, 2008). Overall, tourism, which necessarily involves human-environment interactions, can have severe effects on caves and other components of karst ecosystems. Caves in particular are vulnerable because of the focused intensive nature of visitor use (Ford and Williams, 2007; Pulido-Bosch et al., 1997).

\section{Karst in Puerto Rico}

The island of Puerto Rico is located in the Caribbean, between the Caribbean Sea and the North Atlantic Ocean, east of the Dominican Republic, and about 1,600 km (1,000 mi) southeast of Miami, Florida (Fig. 1). Puerto Rico consists of three physiographic regions: a volcanic central mountainous area (the Cordillera Central) of Late Jurassic to Eocene age, a marginal Tertiary karst belt, and a discontinuous coastal plain (Monroe, 1976; Gardner et al., 1987; Troester, 1992). Carbonate deposition began in the early Cretaceous period but peaked in the early Tertiary period, with deposition of the limestones beginning and ending earlier in the south than the north. After active volcanism and tectonism ceased, extensive middle Oligocene to Pliocene limestones and terrigenous sediments were deposited over the older rocks, particularly along the northern flanks of the mountains, forming the northern karst belt (Monroe, 1976). In the southern karst region, much of the limestone is buried under deep alluvial deposits. The southern limestone is intensely faulted, while the rocks in the north are cut by very few faults (Lugo et al., 2001).

There are marked climatic differences between the northern and southern portions of Puerto Rico, with the north being characterized by a moist, humid climate, while the south is much drier. The southern karst is in a dry, rainshadow location and, superimposed upon the lithological and structural differences noted above, karstification is limited because reduced rainfall inhibits the rate of dissolution (Lugo et al., 2001). Differing lithologies, structures, and climates lead to different rates of karstification and more- or less-developed features, with the north having better-developed karst with more distinctive karst landforms such as cockpits and towers.

Karst covers between 28\% (Lugo et al., 2001) and 34\% of Puerto Rico (Monroe, 1976) and is most extensive in the 


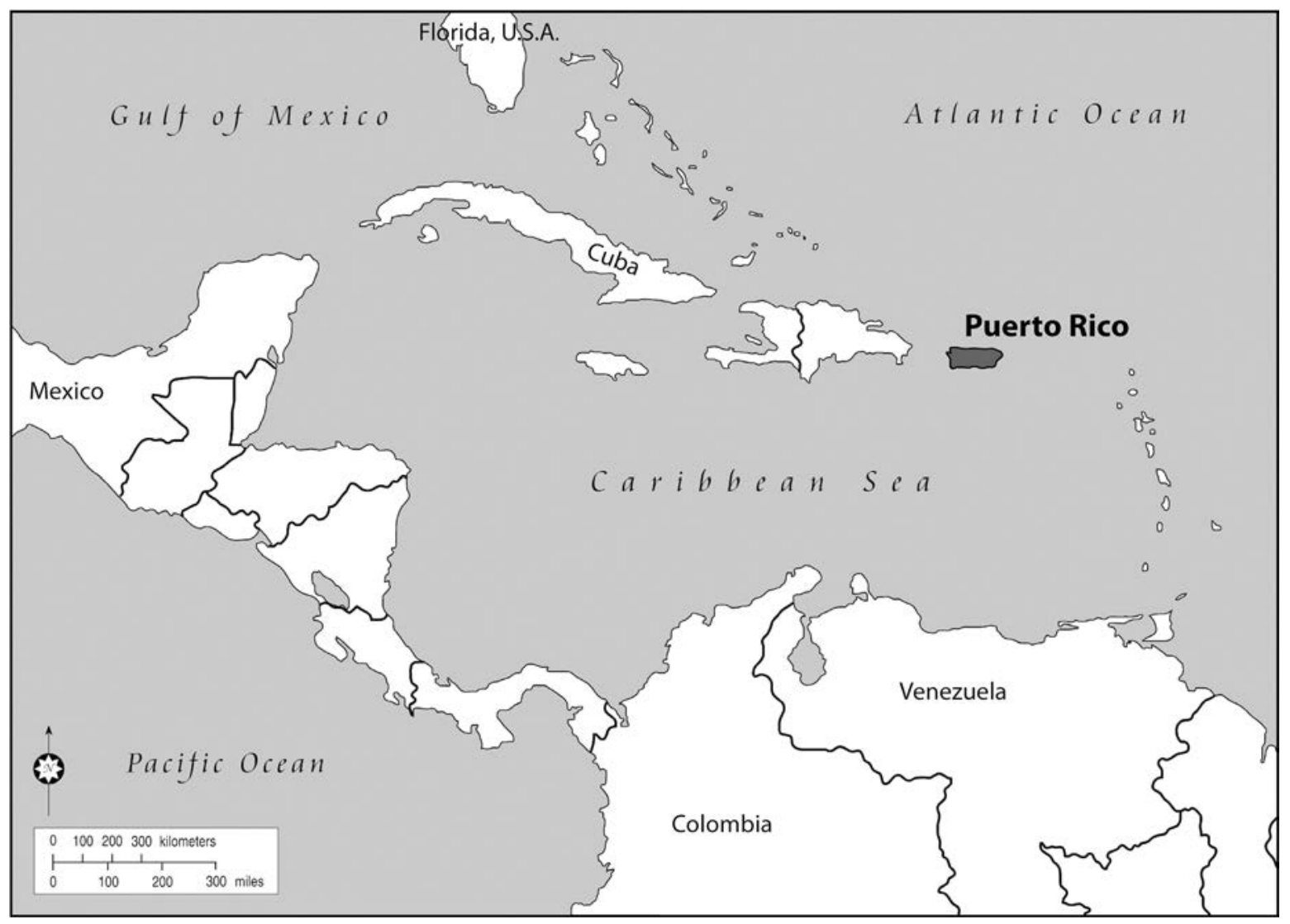

Figure 1. Geographic location of Puerto Rico. Source: adapted from geographyalltheway.com (2012).

northern karst belt, which is the best documented (Monroe, 1976; Troester, 1992; Lugo et al., 2001). The northern karst belt extends about $70 \mathrm{~km}$ east-west parallel to the northern coast west of San Juan, with a maximum width of about $22 \mathrm{~km}$ south of Arecibo. This karst belt encompasses approximately $1,600 \mathrm{~km}^{2}$ or about $20 \%$ of the land area of Puerto Rico (Giusti, 1978) and accounts for about $90 \%$ of the karst in Puerto Rico, with the residual $10 \%$ in the south and in scattered outcrops in the Cordillera Central (Fig. 2).

Six distinct limestone formations are recognized in northern Puerto Rico. In ascending order, they are the San Sebastián Formation, the Lares Limestone, the Cibäo Formation, the Aguada Limestone, the Aymamón Limestone, and the Camuy Formation (Monroe, 1976; Giusti, 1978). The northern karst belt includes extensive areas of dry valleys and sinkholes, together with more dramatic landforms such as cockpits and mogotes (Monroe, 1976; Day, 1978, 2004; Day and Tang, 2004). Mogotes occur particularly along the northern edge of the northern karst belt, and they are perhaps the most distinctive and obvious landforms of the northern karst (Lugo et al., 2001). There are also numerous cave systems (Miller, 2009) and through-flowing allogenic rivers (Monroe, 1976; Lugo et al., 2001).

In the southern karst, four limestone formations are recognized, the Juana Díaz Formation (Oligocene and
Miocene age), the Ponce Limestone (Miocene age), the Guánajibo Formation (late Miocene and possibly Pliocene age) and the Parguera Limestone (Early Cretaceous age) (Lugo et al., 2001). The southern limestone is largely of coral-reef origin and marine limestones outcrop in chalk cliffs of the Juana Díaz Formation near Ponce. This area contains several large caves and closed depressions. Natural windows and rock-shelter caves also occur in the south (Lugo et al., 2001). The landforms in the southern karst region are not as dramatic as those in the north, but the southern karst has been largely ignored and merits further study.

Throughout the Caribbean, human activities have had widespread adverse impacts on karst landscapes (Day, 1993, 2010a,b, 2011), and these are predicted to increase (Day and Chenoweth, 2009). In this context, the northern karst belt of Puerto Rico has an interesting history of colonial agricultural expansion and contraction, followed by depopulation and then urban and industrial encroachment (Pico, 1974; Lugo et al., 2001). It has been regarded as one of the world's most endangered karst areas (Tronvig and Belson, 1999), and it has been a focus of karstconservation efforts on the island (Kueny and Day, 1998; Mujíca-Ortiz and Day, 2001). Paradoxically, although the karst is under extreme human pressure, it still represents the least fragmented natural habitat in Puerto Rico, 


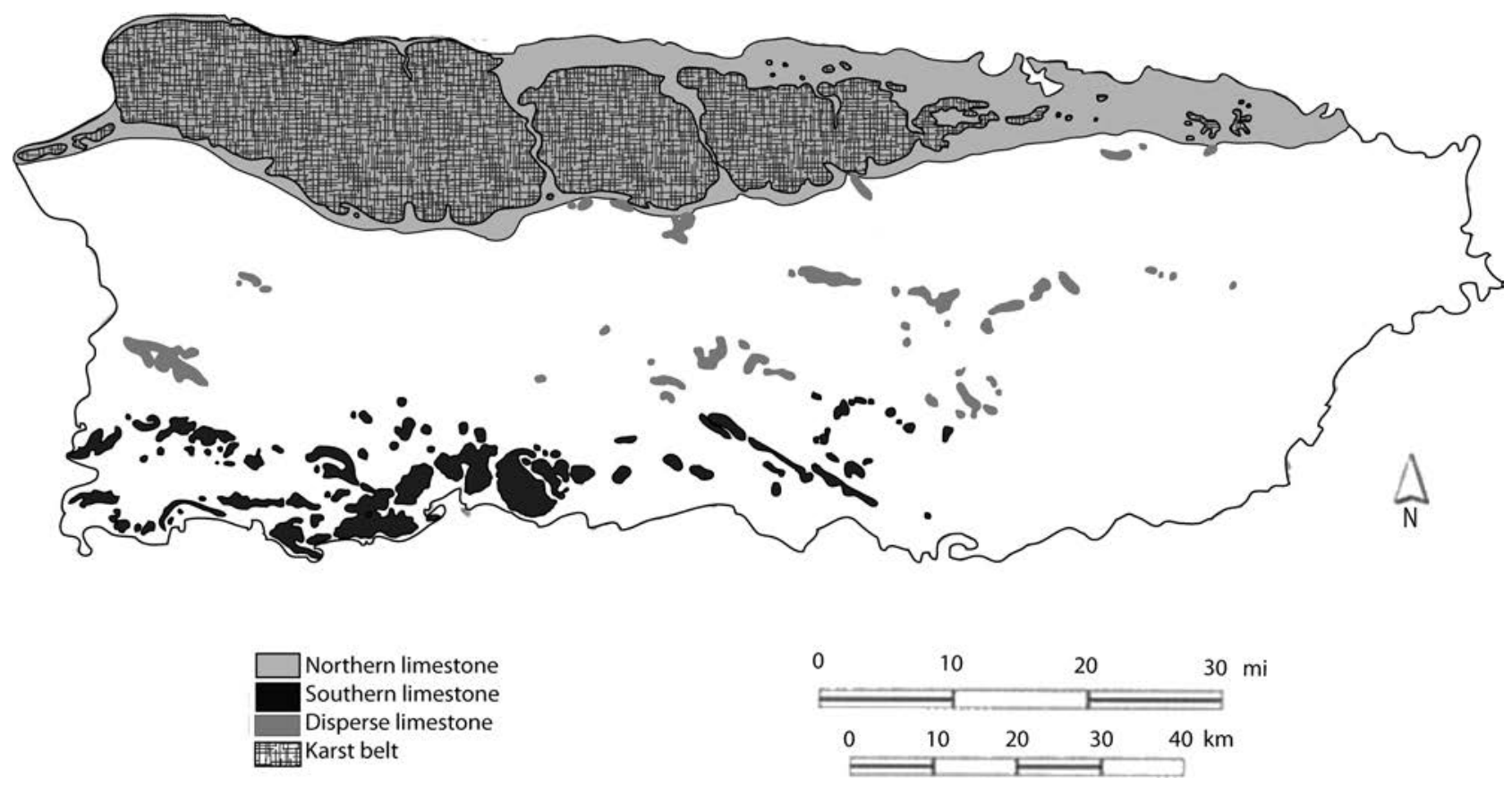

Figure 2. Distribution of karst in Puerto Rico. Source: adapted from Lugo et al. (2001), originally from Monroe (1976).

making its use, conservation, and management all the more critical (Lugo et al., 2001). One approach to reconciling conservation and human activities is through the designation of protected natural areas within which human activities, including tourism, are controlled and closely monitored (Kueny and Day, 1998).

\section{Ecotourism in Puerto Rico}

The definition of ecotourism is complex, multiple definitions exist, and the term has varied meanings to different people and organizations. Although there are a plethora of definitions available to choose from, most definitions include certain criteria. Fennell (2001), for example, suggests that ecotourism is a type of specialty travel that is nature-oriented, promotes conservation, protects local culture, benefits the local population, and promotes education. One of the first (and the most widelyembraced) formal definitions of ecotourism was presented by Ceballos-Lascuráin in 1987 as "traveling to relatively undisturbed or uncontaminated natural areas with the specific objective of studying, admiring, and enjoying the scenery and its wild plants and animals, as well as any existing cultural manifestations (both past and present) found in these areas" (Ceballos-Lascuráin, 1987: p. 14).

Activities conducted under the title of ecotourism are varied and can take place in many different environments (Ceballos-Lascuráin, 1996). Examples include such lowimpact activities as hiking, cycling, rafting, bird-watching, and astronomical observation. Others are limited to specific landscapes and thus are more specialized; caving and scuba diving are examples. Both general and special- ized ecotourism occur in karst landscapes, and tourism is becoming an important aspect of human use of karst areas, with attendant impacts (Huppert et al., 1993; Day, 2010a). The karst also contains diverse and endemic plant and animal populations and provides a wide variety of outdoor activities, while supporting biological, ecological, and geomorphological diversity (Lugo et al., 2001).

Increasingly aware of sustainability issues, Puerto Rico has turned to ecotourism and sustainable development in an effort to conserve and protect its natural resources (Frederique, 2004). With a land area of $13,790 \mathrm{~km}^{2}$ and a population of nearly 4 million people (Central Intelligence Agency, 2010), Puerto Rico has a population density of more than 430.5 people per $\mathrm{km}^{2}$, second in the Caribbean only to Barbados (Scarpaci and Portela, 2009). Sustainable development and ecotourism have become particularly important national issues precisely because of the island's small size and high population density. Protected areas are among the most important venues for ecotourism activity in the Caribbean region (Weaver, 1998; Farrell and Marion, 2001), and well-planned sustainable tourism development should lead not to the deterioration of natural areas but to their conservation (Page and Dowling, 2002).

Specialized tourism in karst landscapes and in protected areas is in some ways analogous to other tourism with particular themes or restricted to specific landscape types, such as religious tourism (Vukonić, 1996), mountain tourism (Nepal and Chipeniuk, 2005), tourism on coral reefs (Hawkins and Roberts, 1994), and archeological tourism (Wallace, 2005). The potential of these distinctive or niche versions of ecotourism is increasing (Weaver, 
1998). At the same time, as protected areas provide a mechanism via which protection of karst areas may be accomplished, they also represent important potential locations for karst-focused tourism and ecotourism (Day and Hall, 2012).

The Caribbean karst, including Puerto Rico, appeals to tourists because of its natural environment and its unique topography, with impressive sinkholes, mogotes, dry valleys, springs, caves, and underground rivers that create unique visitor experiences. The karst also contains diverse and endemic plant and animal populations and provides a wide variety of outdoor activities, while supporting considerable biological, ecological, and geomorphological diversity (Lugo et al., 2001). Tropical karst is often visually striking and creates an immediate and lasting impression on visitors (Day and Hall, 2012). Natural landscapes are valued highly by many tourists and are central to their experience (Mowforth et al., 2008). More significantly, ecotourism is, according to most definitions, dependent on an enjoyable and low-impact experience within the natural environment (Mowforth et al., 2008). It is estimated, internationally, that between 40 and $60 \%$ of tourism is directed toward the appreciation of natural areas (Frederique, 2004), and this suggests that a significant portion of Puerto Rico's tourism must be directed towards the karst, since it represents a significant proportion of the remaining wilderness on the island (Lugo et al., 2001). This is cause both for concern, because of the karst's fragility and the potential impacts of tourism, and for optimism, because ecotourism may provide a vehicle for conservation.

\section{Protected Areas in the Puerto Rican Karst}

Karst landscapes of the Caribbean are in particular need of conservation and sound environmental management because they are inherently fragile and vulnerable to environmental change and human impacts (Day, 1993; Kueny and Day, 1998). The IUCN World Commission on Protected Areas (WCPA) has recognized karst landscapes, including those in the Caribbean, as being at particular risk of degradation and warranting protection (Watson et al., 1997). Pressures on the Caribbean's karst resources are of great concern for environmental, economic, and social reasons (Kueny and Day, 1998; Day, 2010a,b, 2011), and the establishment of protected areas is one way these resources can be conserved. In Puerto Rico, the karst merits conservation because it is "not only a significant portion of the total land area of the island, but it is a particularly important area in terms of its environmental assets" (Lugo et al., 2001: p. 82). As elsewhere in the Caribbean, the designation of protected areas within the Puerto Rican karst is not highly sophisticated, and few areas are protected specifically because they are karst (Mujíca-Ortiz and Day, 2001).

In particular, the karst of Puerto Rico merits conservation to preserve its biodiversity, to promote the recovery of endangered species, to maintain its wilderness nature and spectacular scenery, to ensure scientific and educational opportunities, to maintain open space and recreational potential, and to protect its many environmental functions (Lugo et al., 2001). Recreational potential is inextricably linked to the karst's tourism and ecotourism activities. In addition, the karst of Puerto Rico is extremely important because it possesses spectacular scenery reflecting its diverse landforms, rugged topography, unusual landscapes and contrasting vistas (Lugo et al., 2001). The karst is diverse geomorphologically, hydrologically, and ecologically; it harbors valuable natural resources such as flora and fauna and many endemic and endangered species; and it is economically important due to its water supply (its aquifers and rivers), mining potential (limestone and dolostone), agricultural potential (both subsistence and commercial agriculture), and construction and manufacturing activities (Lugo et al., 2001). Many Taíno archeological sites, including pictographs and petroglyphs, are located in the karst, especially in caves (Frank, 1993). These sites are valuable and should be preserved to protect the culture and history of the island.

Most of the legislation pertaining to protected areas within the Puerto Rican karst has been enacted since 1980, although some legislation is older (Mujíca-Ortiz and Day, 2001). In many instances, protection extends only to specific karst features, such as caves, rather than to the broader scale of drainage basins or ecoregions. Prior to 1999 , only $71 \mathrm{~km}^{2}$ of the karst in Puerto Rico was protected, representing less than 3\% of the total karst area, well below average for the Caribbean (Kueny and Day, 1998; Mujíca-Ortiz and Day, 2001). Lugo et al. (2001) recommended that an additional 39,000 ha of the northern karst belt, representing $27 \%$ of that belt and $16 \%$ of the total karst, should be designated as public lands. In 1999, Law 292 (known as Ley para la Proteccion y Conservacion de la Fisiografia Karsica de Puerto Rico, or more simply, Ley del Karso) was passed to protect $35 \%$ of the karst. The Departamento de Recursos Naturales y Ambientales de Puerto Rico was given the responsibility of completing a study within two years of the law's passage to determine the areas of the karst most needing protection and conservation. This study was not completed until 2008, and implementation has been slow. Figure 3 shows the karst areas protected under the law, as well as state forests and other protected areas. The karst is vulnerable because amendments to Ley del Karso (for example, to authorize construction projects in the karst) are a constant threat and could impact the protected karst areas, including the protected areas in the northern karst belt, the southern karst, and the outcrops in the interior of the island, including natural reserves and state forests (Ciudadanos Del Karso, 2010).

One particularly important mechanism promoting karst protection in Puerto Rico is the creation of state or commonwealth forests, which are the most numerous 


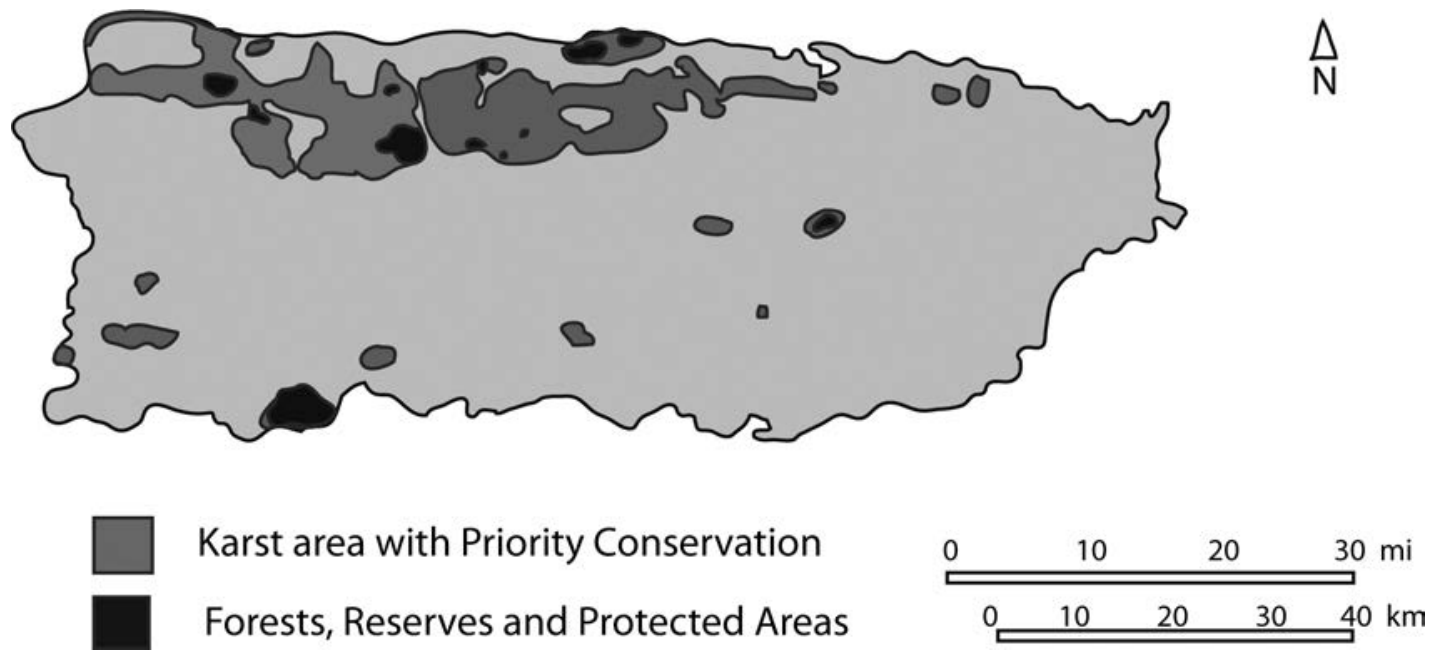

Figure 3. Karst protected under Ley del Karso. Source: adapted from Ciudadanos del Karso (2010).

category of protected areas and occupy the greatest area within the karst (Mujíca-Ortiz and Day, 2001). Under the conditions of Puerto Rico Law Number 133, Ley de Bosques de Puerto Rico, enacted in 1975, state forests are multiple-use areas managed for sustainable use of water resources, timber, wildlife and ecotourism (Frederique, 2004).

There are five state forests in the Puerto Rican karst, Río Abajo, Guajataca, Cambalache, and Vega Alta in the northern karst belt and Guánica in the south (Fig. 4). Of these, Guánica State Forest is the largest, with an area of 4,006 hectares. Río Abajo State Forest is the second largest, at 2,339 hectares, Guajataca State Forest covers 954 hectares, Cambalache 648 hectares, and Vega Alta 504 hectares.

Although the Puerto Rican state forests are not explicitly categorized by IUCN's (International Union for
Conservation of Nature) management categories, broadly they fall within protected area category VI, protected areas with sustainable use of natural resources, "with most of the area in a natural condition, where a proportion is under sustainable natural resource management, and where lowlevel non-industrial use of natural resources compatible with nature conservation is seen as one of the main aims of the area." (IUCN, 2012). Such protected areas incorporate multiple goals and, to be considered successful, must be managed to reconcile conservation objectives with human activities such as ecotourism.

\section{Methods}

Because the state forests are the most numerous and largest protected areas in the Puerto Rican karst, they were selected for further investigation. Ecotourism activities

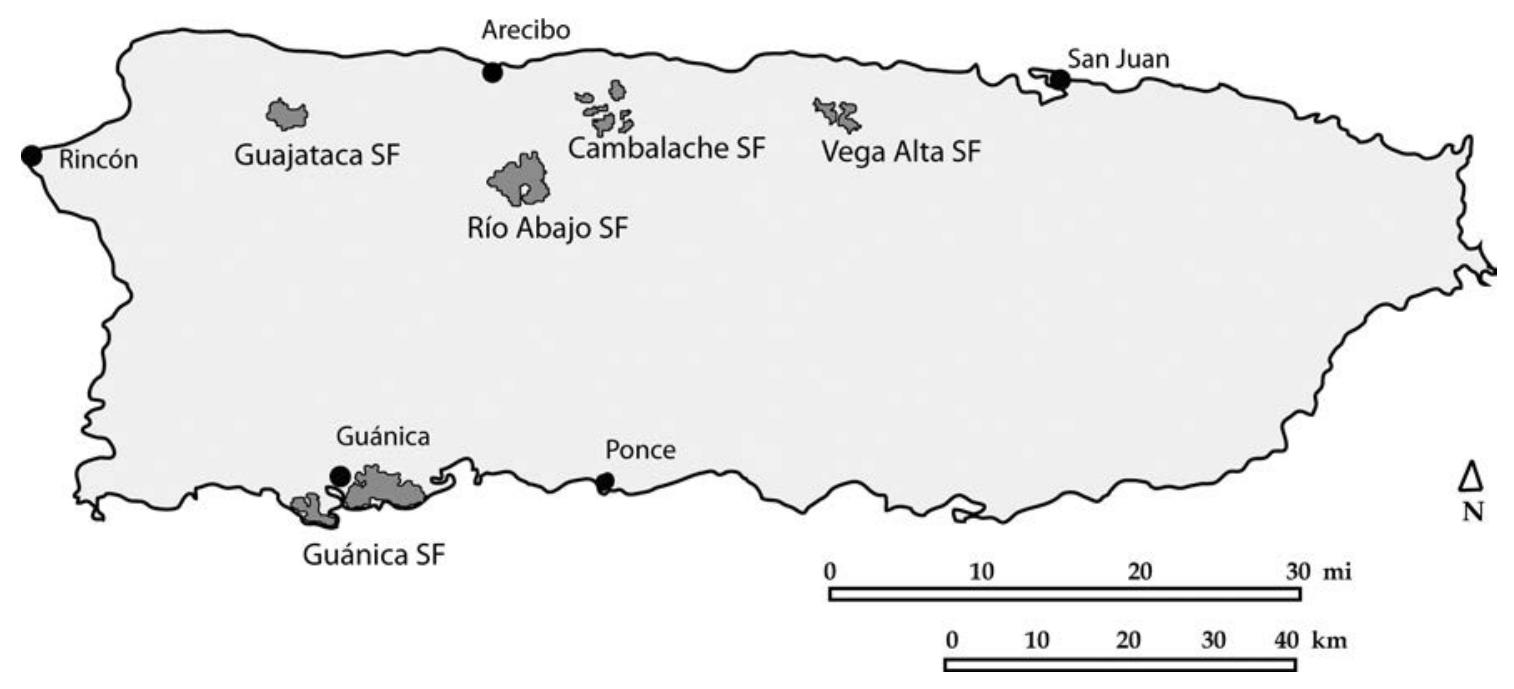

Figure 4. Karst-based State Forests from west to east: Guajataca, Guánica, Río Abajo, Cambalache, Vega Alta. Source: adapted from Hall (2010). 
within the state forests were investigated through literature reviews and field research during 2009 (Hall, 2010). A preliminary analysis of tourism and ecotourism websites was first conducted to discern what types of activities are offered in the karst and to determine where such activities take place. Protected areas, particularly the state forests within the karst, had previously been identified (MujícaOrtiz and Day, 2001), and information about them was obtained via websites and other written sources.

The state forests were then targeted for intensive field investigation. Each state forest was visited, its ecotourism resources and activities were documented, and semistructured interviews were conducted with the forest rangers. Approximate annual tourist numbers collected from the state forests provide a preliminary, if conservative, measure of tourism activity within the karst-based state forests. They also identify the relative significance of the different state forests. Pressures on the karst environment may or may not be directly proportional to the number of visitors participating in karst-based activities. Visitor numbers were reported by rangers as monthly totals and were used to calculate annual totals, resulting in a relatively wide range in annual visitor numbers for each forest. These numbers were then refined on the basis of further information, acquired primarily through ranger interviews. Further details of the research methods are provided by Hall (2010).

\section{RESUlTS}

Located in southwestern Puerto Rico (Fig. 4) in the municipality of the same name, Guánica State Forest is unique among the state forests, both in its location and because it is a UNESCO Biosphere Reserve. Guánica was designated a commonwealth forest in 1917 and subsequently became a forest reserve in 1919 with an area of 3,035 hectares (7,500 acres). Additional land was incorporated in 1931, and the forest now covers 4,006 hectares (9,900 acres), making it the largest of the karstic state forests. Guánica was designated a United Nations International Biosphere Reserve in 1981, and it is now managed cooperatively by the Departamento de Recursos Naturales y Ambientales de Puerto Rico and UNESCO (DRNA, 2010). As a UNESCO biosphere reserve, Guánica is a location where "monitoring, research, education, and training activities are encouraged to support sustainable development" and "the challenge of the biosphere reserve is to educate the growing population to appreciate and maintain Guánica's biological diversity" (UNESCO MAB, 2011).

The Guánica State Forest and Biosphere Reserve is one of the best examples of subtropical dry forest in the United States, and it incorporates two predominant forest types, semi-deciduous forest and cactus forest (Nellis, 1999). The state forest and reserve is also the site of several mangrove cays located in the coastal areas. Ninety percent of the forest is developed on limestone substrate, although because of the semi-arid climate the karst is not as pronounced as in the northern karst belt (DRNA, 2010). Guánica has the greatest bird and plant diversity of any area in Puerto Rico (DRNA, 2010), and it is considered the premier bird-watching site on the island (Nellis, 1999). Eleven of Puerto Rico's fourteen endemic bird species have been recorded in the forest, and over 700 species of plants, including 248 tree species, have been recorded (Nellis, 1999; Mora, 2009). Of the plants, forty-eight are endangered and sixteen are endemic to Guánica (Nellis, 1999).

The biosphere reserve is managed as a multi-use area to foster "harmonious relationships between human activities and the maintenance of the natural ecological integrity" (UNESCO MAB, 2011). Attractions in Guánica include hiking trails, bird-watching, and picnic facilities. There are $57 \mathrm{~km}$ (36 miles) of trails and old roads, including twelve major officially recommended trails. Most visits are daytrips, and camping is not permitted. Visitor records indicate that between 800 and 2,000 people visit Guánica each month, or 9,600 to 24,000 annually, making it the most heavily used of the karst state forests. Because of its international ornithological renown, actual totals are probably at the high end of this range. Usage is highly seasonal, and visitor numbers in some years have reached 20,000 during the summer months alone. Access to the forest is relatively tightly controlled, and an annual total of 20,000 to 24,000 visitors is probably realistic. The ranger confirmed that many people visit the forest to observe and document birds, noting that many educational groups, from primary school to university level, also visit. On request, the ranger presents charlas, or informational talks to these groups, focusing on the unique ecology of the forest. Families and social and religious groups also frequent the picnic sites.

Interviews indicate that visitors to Guánica include Puerto Ricans, travelers from the contiguous US, and international visitors, primarily Europeans, in approximately equal numbers. Visitors from all three categories were encountered during the field visit, and represent a greater diversity than was indicated or observed at any other state forest. Perhaps reflecting the blend of visitors, the forest office provides trail guides and literature about Guánica's natural resources and ecology, including a description of the dry subtropical forest. General literature on the natural resources of Puerto Rico is also readily available.

The other four karst state forests, Cambalache, Río Abajo, Guajataca, and Vega Alta, are located within the northern karst belt, and they share some characteristics in terms of terrain and visitor usage, although they differ somewhat in area, contiguity, history, specificity of purpose, and visitor numbers. All four are readily accessible from San Juan and the north coast and, like Guánica, each has a role in the island's karst ecotourism. Cambalache State Forest is located in the municipalities of 
Barceloneta and Arecibo, Río Abajo is located in the municipalities of Utuado and Arecibo between the Tanamá River and Lago Dos Bocas, Guajataca is in the municipality of Isabela, and Vega Alta is in the municipalities of Vega Alta and Vega Baja (Fig. 4).

The northern state forests have broadly similar histories in terms of their establishment dates and their management purposes. Cambalache was established in 1943 through an agreement between the United States Forest Service and the Autoridad de Tierras de Puerto Rico to implement a forestry program within the karst terrain. In 1975, with the passing of Law 133 (Ley de Bosques de Puerto Rico) the DRNA took over forest management responsibility, the principal function of which is now preservation and conservation of resources for public enjoyment (DRNA, 2010). Río Abajo was also created in 1943 to protect significant drainage basins and aquifers and to implement forest management (DRNA, 2010). Guajataca was donated by the Puerto Rico Reconstruction Administration to the government of Puerto Rico in 1943. Vega Alta was created in 1951, and like the others, is managed by the DRNA, although it is owned by the Autoridad de Tierras de Puerto Rico.

The Cambalache State Forest area of 648 hectares $(1,600$ acres $)$ is distributed between seven separate areas, five in the municipality of Arecibo and two in the municipality of Barceloneta (DRNA, 2010). Cambalache is one of the few preserved areas of lowland karst forest in Puerto Rico and includes more than 150 species of trees, 10 of which are rare or in danger of extinction and at least 15 of which are endemic to Puerto Rico (Nellis, 1999). Seventy percent of the forest covers residual hills or mogotes, providing a dramatic landscape. Cambalache supports the majority of the lowland-forest bird species in Puerto Rico, with the avifauna totaling about 45 species, including 34 permanent resident species and 10 of Puerto Rico's 16 endemic species (DRNA, 2010).

Major recreational attractions in Cambalache include camping areas, gazebos, and barbecue and picnic facilities. There is an $8 \mathrm{~km}$ (about $5 \mathrm{mi}$ ) network of trails for walking, hiking, and mountain biking, and the park encourages astronomical observation, landscape appreciation, birdwatching, hiking, cycling, photography, meditation, and camping.

Visitor records indicate that between 400 and 1,000 people visit Cambalache State Forest each month, or between 4,800 and 12,000 visitors annually. Visitor records probably underestimate total numbers because access is not tightly controlled and not all visitors are recorded. On these grounds, it is estimated that probable visitor numbers are in the upper reach of the range reported. Visitors frequently use the trails for walking, biking, and bird watching, and many school groups visit the forest as part of educational projects. The forest ranger gives presentations about the ecology of the forest, the karst landscape and their importance. Upon reservation, caminatas or nature walks can also be arranged, and literature about the forest is available to visitors who inquire. According to the ranger, the majority of recorded visitors to Cambalache are from the US mainland or international locations. The ranger was of the opinion that relatively few local people utilize the forest, although he described a good relationship with the surrounding community.

Río Abajo covers a contiguous area of 2,339 hectares (5,780 acres) and includes a variety of karst landforms, including cockpits, dry valleys, mogotes, and caves (Nellis, 1999; DRNA, 2010). The majority of the forest is classified as subtropical moist forest, and it includes 175 tree species, 47 of which are threatened or in danger of extinction, and 8 of which are endemic. Following deforestation during the 1940s, the Puerto Rican government started an ongoing reforestation program, with Río Abajo as a focal area (DRNA, 2010).

Recreational facilities in Río Abajo include campsites, hiking trails, and access to a cave system. Visitor records indicate that between 500 and 1,000 people visit Río Abajo each month, or between 6,000 and 12,000 annually. Like Cambalache, visitor records probably underestimate total numbers because access is not tightly controlled and not all visitors are recorded. Camping and hiking are particularly popular activities at Río Abajo, and the cave is a focal point for visitors. School and university classes visit to study and complete educational projects. The ranger gives charlas upon reservation and discusses the ecology of the forest and its relationship to the karst landscape. Trails in Río Abajo are not well marked, and perhaps this is one reason why, according to the ranger, Puerto Ricans are more numerous than international visitors to the forest.

Guajataca covers a smaller contiguous area than Río Abajo (954 hectares or 2,357 acres) (DRNA, 2010) and is classified as subtropical moist forest (Nellis, 1999). The forest is considered a unique natural area because of its distinctive tropical karst topography, including caves, sinkholes, and residual hills (Nellis, 1999). In Guajataca, 186 species of trees have been recorded, of which 23 are endemic to Puerto Rico (Nellis, 1999). The avifauna includes 45 bird species, 8 of which are endemic. Other notable fauna include the Puerto Rican boa, one of the 13 endangered species found in the forest (DRNA, 2010).

Guajataca is designated for multiple uses, including wildlife protection, soil and water conservation, timber production, and outdoor recreation (DRNA, 2010). Attractions include the unique flora and fauna, scenic vistas, Cueva del Viento, a lookout tower that provides an excellent view of the karst landscape, and forty-six hiking trails, totaling $43.5 \mathrm{~km}$ (27 mi.), plus picnic sites and camping facilities. According to the rangers, the camping, picnic, and hiking facilities are what attract most people, although the karst topography, and particularly Cueva del Viento, also attracts visitors. The flora and fauna, especially the endemic species, also attract specialized visitors. Charlas and literature about the forest are also available. 
Visitor records indicate that between 500 and 1,000 people visit Guajataca every month, or 6,000 to 12,000 annually. Like elsewhere, visitor records probably underestimate total numbers because access is not tightly controlled and not all visitors are recorded. A majority of the visitors are from the United States and Europe, although many others are from within Puerto Rico, including families and educational, religious, social, and environmental groups, particularly those involved in tree planting.

Vega Alta, the smallest of the northern karst forests, consists of six non-contiguous areas, and its principal purpose is conservation of the natural area, including the karst landscape (DRNA, 2010). The forest covers a total of 504 hectares $(1,245$ acres $)$ of moist subtropical forest based primarily on mogote and ridgetop karst topography (Nellis, 1999; DRNA, 2010). There are at least 72 tree species, 6 native plant species, and 15 bird species, including 3 endemics (DRNA, 2010).

Attractions in Vega Alta include three poorly marked hiking trails and a small picnic area near the rather inconspicuous ranger station. The trails and picnic area are available daily and excursions are available upon reservation, although the ranger is only available at this location on Tuesday and Thursday mornings. According to the ranger, 500 to 1,000 people visit Vega Alta annually, although visitors are not documented here as accurately as in the other state forests. Because the forest is fragmented and because its principal objective is conservation of the flora, fauna and karst landscape, tourism is largely not encouraged. There are few international visitors and most visitors are local residents and/or school groups.

\section{ANALYSIS}

The state forests are an important ecotourism focus in the karst landscape of Puerto Rico. Numerous ecotourism activities take place in the karst landscape, and many of these are focused primarily or exclusively on the five state forests. Cumulatively, annual visitor numbers total between 27,000 and 61,000, probably at the upper end of this range. Overall, it is estimated that between $25 \%$ and $40 \%$ of ecotourism in Puerto Rico takes place within the karst (Hall, 2010), and on the basis of the visitor numbers above, approximately 5 to $15 \%$ of the ecotourism activity within the karst takes place within the state forests. This range is an estimate and is probably conservative.

One reason why visitors are drawn to the state forests in the karst is that tourism guidebooks draw particular attention to them, both as attractive and interesting destinations and as sites for nature-based activities. Some of this attention is simply because the forests represent accessible natural areas, but it at least partly reflects the realization and acknowledgement that the karst itself is a worthwhile destination, not only for its relatively undisturbed nature, but also because of the inherent character- istics of the karst landscape and its ecology. Thus, the state forests are significant both as sites for general ecotourism activities and as sites for ecotourism focusing on the specific nature of the karst itself.

The protected areas, as represented by the state forests, play several pivotal and intersecting roles with respect to tourism within the karst. First, they are representative of the least fragmented natural habitat in Puerto Rico, and are thus automatic candidates for ecotourism, which, by definition, focuses on an enjoyable experience within natural areas with minimal (low impact) human disturbance (Mowforth et al., 2008; Ceballos-Lascuráin, 1996). Although one of the goals of ecotourism is minimal human disturbance, "protected area visitation may degrade natural resources, particularly in areas of concentrated visitor activities like trails and recreation sites." (Farrell and Marion, 2001: p. 215). As visitor numbers increase, this may become a matter of increasing concern because of the inherent vulnerability of the karst landscape.

Second, they provide access, facilitating entry into the karst and utilization of the landscape. Major roads across the karst often follow the major valleys, and many minor roads follow courses of dry valleys. These roads represent the primary routes via which the majority of visitors enter and traverse the karst, although others access the karst on foot, on horse, or via rivers by tube, canoe, kayak, or swimming (Hall and Day, 2011). Not entirely incidentally, the state forests are located away from major throughflowing rivers, and the primarily road access provides a mechanism for regulation and control of tourist activity within the karst, for example, through the opening and closing of access gates on a daily or longer-term basis. Forest rangers play a role in disseminating and enforcing environmental protection regulations.

Third, the forests within the karst provide a location for a wide variety of ecotourism activities, such as hiking, birdwatching, astronomy, and cave exploration, some of which might take place in any natural area, but others are specific to the karst. In this sense, the forests function as both general and specific ecotourism sites (Hall, in preparation). In addition, the forests play many important roles within the local community environment. According to a study of public knowledge and perception of the karst forests (López-Marrero et al., 2011), local residents believe that the forests provide multiple services, with the most significant roles being as a source of forest products, as a mechanism of temperature regulation, as a habitat for flora and fauna, as an aid in air purification, and by providing recreational facilities. Sixty percent of respondents specifically associated the Puerto Rican karst forests with recreational opportunities.

Fourth, the forests play a significant educational role within the karst. With the possible exception of Vega Alta, the forests place an emphasis on providing opportunities for educational activities within ecotourism, focusing on karst hydrology, geomorphology, and biogeography.

Journal of Cave and Karst Studies, April 2014 • 37 
Through the forests, ecotourists learn about karst and cave development, karst ecology, and other aspects of karst science. The forest staffs also play an important role in communicating information (either via talks or by simply distributing literature) about all that the forest has to offer in the way of wildlife and other opportunities, as well as threats to the karst, such as the potential for water contamination and rapid transfer of pollutants. Additionally, the forests represent an important habitat for wildlife and thus serve as a major focus for wildlife viewing and tracking, particularly bird-watching, which is one of the primary ecotourism activities (Raffaele, 1989). Land protection and ecotourism use of protected areas often result in positive attitudes toward protection that are stimulated by environmental education (Eagles, 1999). The situation in Puerto Rico broadly mirrors other karst regions. For example, in Belize, education about the karst is provided by wardens at protected areas operated by the Belize Audubon Society (Bundschuh et al, 2007).

Many of the ecotourism activities within the karst use the protected areas in multiple and complementary ways, combining access, entertainment, and education. In themselves, the forests represent both controlled habitats and recreational sites within the karst, and they play multifaceted roles. For example, hiking is a basic component of much of the karst-based ecotourism, either as the primary activity or as a means to other ends, such as climbing, cave exploration, or bird-watching. Many hiking trails enter the karst via protected areas, and many organized hikes begin or end there, particularly providing post-hiking relaxation opportunities. This recreational focus within the protected areas is peculiar to Puerto Rico; other regional protected karst areas place a greater emphasis on conservation, with less concern for tourism (Bundschuh et al., 2007; Day, 2010a, 2011).

Karst itself is of variable importance to the ecotourism activities (Hall, 2010; Hall, in preparation). Some, such as caving, are karst-specific, while others are less intimately focused on the karst itself. Ecotourism activities within protected areas predominantly fall into the latter category, but nevertheless, the protected areas themselves represent an important locational focus. Although ecotourism activities take place throughout the karst, water resources such as rivers, sinks, and springs are often an important focus (Hall and Day, 2011). Because the karst forests are such accessible venues for local recreation, ecotourism here is perhaps less karst-specific than in other karst areas of Central America and the Caribbean, where visiting the karst requires greater planning and dedication (Bundschuh et al., 2007).

Although all of the protected areas provide potential ecotourism sites, numerically the Guánica State Forest is currently the most important protected area for ecotourism in the karst of Puerto Rico. This reflects its status as a UNESCO Biosphere Reserve and its importance as a birdwatching destination, which more than compensate for its relative inaccessibility from San Juan. The attraction of the Guánica avifauna owes much to the karst topography and vegetation, so the ecotourism here is moderately karstspecific, more so than in many other regional karst tourism sites (Day and Hall, 2012).

Within the northern karst belt, the Río Abajo, Guajataca, and Cambalache State Forests currently report similar visitor numbers, with Vega Alta reporting significantly fewer visitors. These numbers are probably conservative, but they appear reasonable considering factors such as scenic attractions, accessibility, size, recreational versus conservation emphasis, and proximity to other attractions. Guánica is the largest of the state forests and also attracts the most visitors, while Vega Alta is the smallest and has the least visitors. Guajataca, Cambalache, and Río Abajo State Forests attract approximately the same numbers of visitors, although Río Abajo is significantly larger than the other two. Given the state forest areas, numbers of visitors and visitor densities probably fall centrally within the ranges reported elsewhere (Bundshcuh et al., 2007; Day and Hall, 2012).

There are several factors that may contribute to Río Abajo (2,339 ha), Guajataca (954 ha) and Cambalache (648 ha) state forests attracting approximately the same visitor traffic including their proximity to each other, as well as to other scenic attractions, access, and recreational and scenic opportunities. All three state forests are located in the northwest karst belt (Fig. 4) and all three are easily accessible via major roadways. They are within easy driving distance of each other, and they are also in close proximity to karst-based tourist attractions such as the Arecibo Observatory and the Río Camuy Cave Park.

All three state forests offer similar outdoor recreational activities, including designated recreational areas, camping, trails for hiking, mountain biking, and walking, and picnic facilities. All three offer scenic vistas of the karst landscape. Río Abajo and Guajataca State Forests have significantly more hiking trails than Cambalache State Forest. Río Abajo and Guajataca State Forests both contain publicly accessible caves; Cambalache does not. Most guidebooks list the three state forests together when suggesting outdoor recreational options in the northern karst landscape.

It is also important to consider the recreational carrying capacity of the state forests, in other words, "the character of use that can be supported over a specified time by an area developed at a certain level without causing excessive damage to either the physical environment or the experience of the visitor" (Lime and Stankey, 1971: p. 175). Management strategies to promote conservation through education can significantly change visitor attitudes toward the environment and, in turn, help to decrease recreational impact on physical resources. For example, brochures about low-impact camping distributed at the entrance station in a forest campground reduced tree damage and litter in campsites by between 50 and $80 \%$ (Oliver et al., 1985). 
It is unknown to the authors whether or not specific recreational carrying capacities have been calculated for the karst state forests in Puerto Rico, but further research into this is indicated. Current levels of visitor activity at each of the forests suggest that such carrying capacities, if they have been established, are not be exceeded at present and are unlikely to be surpassed in the immediate future. Carrying capacities within karst landscapes may be even more important considerations than in other landscapes because of their inherent fragility, and they have already proved to be important tools elsewhere within karst landscapes, for example in assessing appropriate visitor numbers for tourist caves (Cigna and Burri, 2000). Assessing the broader recreational capacities of the landscapes within the state forests represents a greater challenge, but needs further consideration.

There is some inherent conflict in the promotion of ecotourism in karst landscapes in general, as exemplified in the contradictions involved in attempting to protect caves yet also introducing and exposing them to visiting tourists (Fleury, 2009). Overall, the karst state forests appear to be successful in providing ecotourism opportunities and reconciling these activities with conservation goals. Although self-promotion by the forests is minimal, information about them is readily available via tourist literature, particularly through the internet, and by means of the Departamento de Recursos Naturales y Ambientales website (DRNA, 2010). Both residents and visitors appear well aware of the forests, although the relative proportions of each visiting specific forests varies, for example with Vega Alta having mostly local usage and international birdwatchers focusing on Guánica. All of the forests provide recreational and educational opportunities, but these are well-focused and their scope does not appear to conflict with broader ecological and conservation goals.

Recreational pressures within the forests are heaviest near access points, in designated high-usage locations such as picnic areas, along designated trails, and at sites such as lookout points and cave entrances. These pressures, which are exacerbated during weekends and over public holidays, appear to be generally well-managed, with only minimal vegetative degradation in picnic areas and limited vandalism at cave entrances. Trails appear generally in good condition, and there is little apparent adverse impact on the overall karst landscape or on the vegetation or wildlife. Littering is a recurrent problem in heavily visited areas, but is manageable and decreases rapidly away from picnic areas and short trails. The forests are afflicted by barely adequate financial and personnel resources, but they nevertheless manage to fulfill important roles both in karst landscape conservation and ecotourism. Again, a paucity of parallel studies makes it difficult to compare this situation to that in other regional karst areas, but there are certainly parallels with protected and recreational karst areas in Belize (Bundschuh et al., 2007) and elsewhere in the Caribbean (Day, 2010b, 2011).
Although the state forests are broadly comparable to other IUCN Category VI protected areas regionally and internationally, they are restricted in size, reflecting the limited area and considerable population density of Puerto Rico, but this does not seem to compromise their effectiveness. They share some similarities with U.S. mainland state forests (Ceballos-Lascuráin, 1996), although the latter generally have a greater emphasis on conservation and a lesser role in recreational ecotourism. They may be more similar to U.S. mainland state parks, where recreational activities share equal prominence with ecosystem conservation.

It is difficult to compare directly the importance of ecotourism in the Puerto Rican karst forests with that in other karst landscapes, even within Central America and the Caribbean, but there exist some broad similarities, even though visitor numbers themselves here are far lower than at other specific karst sites in the region (Day and Hall, 2012). As a percentage of a country's overall tourism, the Puerto Rican karst is somewhat lower than in Belize (Bundschuh et al., 2007) and Jamaica (Day and Hall, 2012), but it is probably representative of broader patterns elsewhere in the karst of Central America and the Caribbean. What sets the Puerto Rican karst state forests apart, however, is their relatively small areas, their accessibility, their primacy as ecotourism foci, and their importance to local populations as opposed to international visitors (with more variation seen in the Guànica case).

\section{Conclusions}

Although not every visitor or resident wants to explore Puerto Rico's natural areas, a significant number and percentage of both are increasingly interested in alternative or ecotourism, and it is clear that the karst represents an important focus for this sort of activity. Although there are alternative destinations, such as El Yunque (the Caribbean National Rainforest) and sites in the Cordillera Central, the karst constitutes much of the remaining natural landscape in Puerto Rico.

Even though the state forests are limited in area in the karst of Puerto Rico, they play a pivotal role in influencing ecotourism in the karst, which is itself a major tourism focus. In particular, the state forests provide access, userfriendly sites, information, and educational opportunities that are used by residents and visitors alike to maximize their use and enjoyment of the karst. The state forests provide access to and through the karst landscape. Many of the ecotourism activities within the state forests, such as hiking and bird-watching, are strongly linked to the karst landscape and its ecology. The state forests also play a significant educational role, particularly in making available information about the development and formation of karst landforms.

The state forests play a pivotal role in human use of karst areas, particularly in recreation and tourism. Karst 
landscapes provide significant venues for ecotourism, and the forests play a major role in promoting recreational activities and tourism opportunities. Without them, levels of ecotourism within the karst would be considerably reduced, so, although limited in numbers and area, they provide critical recreational and economic resources in the Puerto Rican karst landscape.

Finally, although the Puerto Rican karst state forests are small in number and area, and although their visitor numbers are relatively low in comparison with other tropical karst venues (Day and Hall, 2012), they represent a critical conservation and recreational element within a densely populated Caribbean island with few remaining intact ecosystems (Lugo et al., 2001). Puerto Rico has a stronger economic base than many other countries in Central America and the Caribbean (Central Intelligence Agency, 2010), so costs of, and revenues from, protectedarea tourism play only a minor economic role, one that is far outweighed by conservation of the island's remaining karst forests and the provision of appropriate educational and recreational opportunities.

\section{REFERENCES}

Bundschuh, J., Birkle, P., Finch, R.C., Day, M., Romero, J., Paniagua, S., Alvarado, G.E., Bhattacharya, P., Tippmann, K., and Chaves, D., 2007, Geology-related tourism for sustainable development, in Bundschuh, J., and Alvarado, G.E., eds., Central America: Geology, Resources, Hazards: London, Taylor \& Francis, v. 2, p. 1015-1098. doi: 10.1201/9780203947043.ch34.

Ceballos-Lascuráin, H., 1987, The future of ecotourism: Mexico Journal, January 1987, p. 13-14.

Ceballos-Lascuráin, H., 1996, Tourism, Ecotourism, and Protected Areas: The State of Nature-Based Tourism Around the World and Guidelines for Its Development: Gland, Switzerland, International Union for the Conservation of Nature and Natural Resources, 293 p. doi:10.2305/IUCN.CH.1996.7.en.

Central Intelligence Agency, 2010, World Fact Book, Puerto Rico. https:// www.cia.gov/library/publications/the-world-factbook/geos/rq.html [accessed February 3, 2010].

Cigna, A.A., and Burri, E., 2000, Development, Management and Economy of Show Caves. International Journal of Speleology, 29B (1/4), p. 1-27.

Ciudadanos del Karso, 2010, Puerto Rico, www.cdk-pr.org, [accessed May 3, 2012]

Coghlan, A., 2008, Even the quietest ecotourists can scare away wildlife: New Scientist, 13 August 2008, 10 p. doi:10.1016/S0262-4079(08) 62030-8.

Day, M.J., 1978, Morphology and distribution of residual limestone hills (mogotes) in the karst of northern Puerto Rico: Bulletin of the Geological Society of America, v. 89, no. 3, p. 426-432. doi:10.1130/ 0016-7606(1978)89<426:MADORL > 2.0.CO;2.

Day, M.J., 1993, Human impacts on Caribbean and Central American karst, in Williams, P.A., ed., Karst Terrains: Environmental Changes and Human Impact: Reiskirchen, Germany, Catena Supplement 25, p. $109-125$.

Day, M.J., 2004, Cone karst, in Gunn, J., ed., Encyclopedia of Caves and Karst Science: New York, Taylor and Francis, p. 241-243.

Day, M.J., 2010a, Human interaction with Caribbean karst landscapes: past, present and future: Acta Carsologica, v. 39, no. 1, p. 137-146.

Day, M.J., 2010b, Challenges to sustainability of the Caribbean karst: Geologia Croatica, v. 63, no. 2, p. 149-154. doi:10.4154/gc.2010.12.

Day, M.J., 2011, Protection of karst landscapes in the developing world: lessons from Central America, the Caribbean, and Southeast Asia, in: van Beynen, P.E., ed., Karst Management: Amsterdam, Springer, p. 439-458. doi:10.1007/978-94-007-1207-2_21.
Day, M.J., and Chenoweth, M.S., 2004, Cockpit Country cone karst, Jamaica, in Gunn, J., ed., Encyclopedia of Caves and Karst Science: New York, Taylor and Francis, p. 233-235.

Day, M.J., and Chenoweth, M.S., 2009, Potential impacts of anthropogenic environmental change on the Caribbean karst, in Barker, D., Dodman, D., and McGregor, D., eds., Global Change and Caribbean Vulnerability: Environment, Economy and Society at Risk: Kingston, UWI Press, p. 100-122.

Day, M.J., and Hall, A.B., 2012, On tourism in tropical karst: Cave and Karst Science, v. 39, no. 3, p. 119-122.

Day, M.J., and Tang, T., 2004, Tower karst, in Gunn, J., ed., Encyclopedia of Caves and Karst Science: New York, Taylor and Francis, p. 734-736.

DRNA, Departamento de Recursos Naturales y Ambientales, Puerto Rico, 2010, www.drna.gobierno.pr. [accessed February 3, 2010].

Eagles, P.F.J., 1999, Ecotourism and environmental education: relationships: Pathways: The Ontario Journal of Outdoor Education, v. 12, no. 2 , p. $15-17$.

Farrell, T.A., and Marion, J.L., 2001, Identifying and assessing ecotourism visitor impacts at eight protected areas in Costa Rica and Belize: Environmental Conservation, v. 28, no. 3, p. 215-225. doi:10.1017/S0376892901000224.

Fennell, D.A., 2001, A content analysis of ecotourism definitions: Current Issues in Tourism, v. 4, no. 5, p. 403-421. doi:10.1080/13683500108667896.

Fleury, S., 2009, Land Use Policy and Practice on Karst Terrains: Living on Limestone. New York, Springer, 187 p. doi:10.1007/978-1-4209670-9.

Ford, D.C., and Williams, P.W., 2007, Karst Hydrogeology and Geomorphology: Chichester, UK, Wiley, $562 \mathrm{p}$.

Frank, E.F., 1993, Aspects of karst development and speleogenesis, Isla de Mona, Puerto Rico: An analogue for Pleistocene speleogenesis in the Bahamas [MS thesis]: Mississippi State University, $282 \mathrm{p}$.

Frederique, E.A., 2004, Turísmo, medio ambiente y áreas naturales protegidas en Puerto Rico: Perspectivas y retos para alcanzar el desarrollo sostenible en este sector en el estado libre asociado de Puerto Rico: San Juan, Colegio de Agrónomos de Puerto Rico, 54 p.

Gardner, T.W., Back, W., Bullard, T.F., Hare, P.W., Kesel, R.H., Lowe, D.R., Menges, C.M., Mora, S.C., Pazzaglia, F.J., Sasowski, I.D., Troester, J.W., and Wells, S.G., 1987, Central America and the Caribbean, in Graf, W.L., ed., Geomorphic Systems of North America: Boulder, Geological Society of America, Centennial Special Volume 2, p. 347-353.

geographyalltheway.com, Online Geography and Humanities Resources, 2012, found at: http://alabamamaps.ua.edu/contemporarymaps/world/ americas/Caribbean \%20and\%20Central\%20America \%20outline.jpg, [accessed May 2, 2012].

Giusti, E.V., 1978, Hydrogeology of the Karst of Puerto Rico: U.S. Geological Survey Professional Paper 1012, 68 p.

Hall, A.B., 2010, Ecotourism in the Karst Landscape of Puerto Rico [MS Thesis]: University of Wisconsin-Milwaukee, $151 \mathrm{p}$.

Hall, A.B., and Day, M.J., 2011, Water as a focus of ecotourism in the karst of Puerto Rico: Tourism and Karst Areas, v. 4, no. 1, p. 17-25.

Hall, A.B. in preparation: Specificity of ecotourism and tourism in tropical karst landscapes, Current Issues in Tourism.

Hawkins, J.P., and Roberts, C.M., 1994, The growth of coastal tourism in the Red Sea: Present and future effects on coral reefs: Ambio, v. 23, no. 8 , p. $503-508$.

Huppert, G., Burri, E., Forti, P., and Cigna, A.A., 1993, Effects of tourist development on caves and karst, in Williams, P.A., ed., Karst Terrains: Environmental Changes and Human Impact: Reiskirchen, Germany, Catena Supplement 25, p. 251-268.

IUCN, 2012, IUCN Protected Area Management Categories. http://www. iucn.org/about/work/programmes/gpap_home/gpap_quality/gpap_ pacategories/ [accessed February 3, 2012].

Kueny, J.A., and Day, M.J., 1998, An assessment of protected karst landscapes in the Caribbean: Caribbean Geography, v. 9, no. 2, p. $87-100$

Lime, D.W., and Stankey, G.H., 1971, Carrying capacity: maintaining outdoor recreational quality, in Larson, E.vH., ed., Recreation symposium proceedings, October 12-14, 1971, Syracuse, New York: Upper Darby, Pennsylvania: USDA Forest Service, Northeastern Forest Experiment Station, p. 174-184.

Lobo, H.A.S., and Moretti, E.C., 2009, Tourism in caves and the conservation of the speleological heritage: The case of Serra da 
Bodoquena (Mato Grosso do Sul State, Brazil): Acta Carsologica, v. 38 , no. $2-3$, p. $265-276$.

López-Marrero, T., Marianna, M., Nieves-Crespo, H.I., Morales-López, R., Nieves-Rodrigues, E., and Balloffet, N.M., 2011, Public knowledge and Perceptions about Karst Forests. [ConoBosque Briefing]. San Juan, PR: Mision Industrial de Puerto Rico, 10 p.

Lugo, A.E., Castro, L.M., Vale, A., López, T., Prieto, E.H., Martinó, A.G., Puente Rolón, A.R.P., Tossas, A.G., McFarlane, D.A., Miller, T., Rodríguez, A., Lundberg, J., Thomlinson, J., Colón, J., Schellekens, J.H., Ramos, O., and Helmer, E., 2001, Puerto Rican Karst-A Vital Resource: U.S. Department of Agriculture, Forest Service, General Technical Report WO-65, 100 p.

Miller, T., 2009, Puerto Rico, in Palmer, A.N., and Palmer, M.V., eds., Caves and Karst of the USA: Huntsville, National Speleological Society, p. 332-345.

Monroe, W.H., 1976, The Karst Landforms of Puerto Rico: U.S. Geological Survey Professional Paper 899, 68 p.

Mora, M.C., 2009, Aspectos Ecológicos y Descripción de Hábitat de un Bosque Seco Subtropical: Reserva Forestal de Guánica Reserva de la Biósfera. Collected in 2009, Guánica State Forest and Biosphere Reserve.

Mowforth, M., Charlton, C., and Munt, I., 2008, Tourism and Responsibility: Perspectives from Latin America and the Caribbean: New York, Routledge, 243 p.

Mujíca-Ortiz, B., and Day, M.J., 2001, Karst conservation and protected areas in northern Puerto Rico: Caribbean Geography, v. 12, no. 1, p. 11-23.

Nellis, D.W., 1999, Puerto Rico and Virgin Islands Wildlife Viewing Guide: Falcon, 95 p.

Nepal, S.K., and Chipeniuk, R., 2005, Mountain tourism: toward a conceptual framework: Tourism Geographies, v. 7, no. 3, p. 313-333. doi:10.1080/14616680500164849.

Oliver, S.S., Roggenbuck, J.W., and Watson, A.E., 1985, Education to reduce impacts in forest campgrounds: Journal of Forestry, v. 83, no. 4 , p. $234-236$

Page, S.J., and Dowling, R.K., 2002, Ecotourism: New York, Prentice Hall, Themes in Tourism, $338 \mathrm{p}$.
Pico, R., 1974, The Geography of Puerto Rico: Chicago, Aldine Publishing Co, 439 p.

Pulido-Bosch, A., Martín-Rosales, W., López-Chicano, M., RodríguezNavarro, C.M., and Vallejos, A., 1997, Human impact in a touristic karstic cave (Aracena, Spain): Environmental Geology, v. 31, no. 3/4, p. 142-149. doi:10.1007/s002540050173.

Raffaele, H.A., 1989, A Guide to the Birds of Puerto Rico and the Virgin Islands, Revised Edition: Princeton University Press, 272 p.

Scarpaci, J.L., and Portela, A.H., 2009, Cuban Landscapes: Heritage, Memory, and Place: London and New York, The Guilford Press, $215 \mathrm{p}$.

Scott, T.M., Means, G.H., Meegan, R.P., Means, R.C., Upchurch, S.B., Copeland, R.E., Jones, J., Roberts, T., and Willet, A., 2004, Springs of Florida: Florida Geological Survey Bulletin 66, 658 p.

Troester, J.W., 1992, The northern karst belt of Puerto Rico: a humid tropical karst, in Back, W., Herman, J.S., and Paloc, H., eds., Hydrogeology of Selected Karst Regions: Hannover, Verlag Heinz Heise, p. 475-486.

Tronvig, K., and Belson, C.S., 1999, Karst Waters Institute's second annual top ten list of endangered karst ecosystems: NSS News, September 1999, p. 265-267 and 283.

UNESCO, United Nations Educational, Scientific and Cultural Organization, 2011, MAB Biosphere Reserves Directory, http://www.unesco. $\mathrm{org} / \mathrm{mabdb} / \mathrm{br} / \mathrm{brdir} /$ directory $/$ biores. asp? $\mathrm{code}=\mathrm{USA}+35 \& \operatorname{mode}=$ all [accessed June 11, 2011].

Vukonić, B., 1996, Tourism and Religion: Oxford, Pergamon, Elsevier Science Ltd., Tourism Social Science Series, 208 p.

Wallace, T., 2005, Tourism, Tourists and Anthropologists at Work: National Association for the Practice of Anthropology Bulletin, v. 23, no. 1, p. 1-26. doi:10.1525/napa.2005.23.1.1.

Watson, J., Hamilton-Smith, E., Gillieson, D., and Kiernan, D.K., 1997, Guidelines for cave and karst protection: Gland, Switzerland, International Union for Conservation of Nature, $63 \mathrm{p}$. (http://data. iucn.org/dbtw- wpd/edocs/1997-026.pdf).

Weaver, D.B., 1998, Ecotourism in the Less Developed World: Wallingford, Oxfordshire, UK, CAB International, $288 \mathrm{p}$. 